\title{
6
}

\section{Reflections on Brij Lal's Girmityas: The Origins of the Fiji Indians}

\author{
Ralph Shlomowitz and Lance Brennan
}

In Brij Lal's first monograph, Girmityas: The Origins of the Fiji Indians (1983), a number of central issues are addressed: the structure and operation of the recruitment system (Chapter 1), the regional origins of the migrants (Chapter 2), their social and economic background in India (Chapter 3), and the migration of women and children (Chapters 4 and 5). In the three decades since the publication of this monograph, our research group at Flinders University has addressed a set of related topics on the history of the health of Indians at home and abroad. Our first project focused on the health of indentured workers, including those going to Fiji, while in the second project, using John McDonald's econometric expertise, we attempted an anthropometric history of India (Shlomowitz 1996: chs 4, 6, 9, 11, 14; Brennan, McDonald and Shlomowitz 2013). This project owed its origins to Ralph noticing individual height data on the Emigrant Pass on the back cover of Girmityas. As a student of Robert Fogel, a pioneer of anthropometric history, he perceived the possibility of constructing a systematic analysis of changes in the welfare of rural Indians during the indentured labour period-if other emigrant passes and shipping lists included data on individual height as well as on age, caste and district of origin. They did. In this project, we followed Lal's lead in quantifying the data included in the Emigrant Passes of workers who departed from Calcutta, and then extended this to include those departing from Madras. These research projects have brought forth new evidence 
and new insights on many of the topics addressed by Lal. This chapter is not an evaluation of Lal's work. Rather, it offers a series of reflections on how Lal's pioneering scholarship can be fruitfully extended. These reflections are limited to Lal's first three chapters as we have little to add to the chapters on women and children.

In his first chapter, 'A Journey Begins', Lal argues that the success of recruitment depended on relative economic conditions: in 'a period of relative prosperity ... Indians naturally expressed a reluctance to leave their homes', while in 'years of drought, scarcity and famine ... distressed peasants sought any alternative to alleviate their grim conditions' (1983: $25,26)$. Lal then shows that the number of recruits who were 'rejected as unfit' in sub-depots before despatch to Calcutta and between arrival in the Calcutta depot and departure for overseas were more marked in the years of famine and scarcity as recruiting authorities could then be more selective of who they permitted to go overseas $(29,31)$. The specific reasons why the recruiting authorities 'rejected as unfit', Lal suggests, 'are difficult to ascertain as our sources do not go beyond giving statistical aggregates' (30).

As one of our main sources used in investigating changes in the average height of Indians before World War I was the height of indentured workers that were recorded in the Emigrant Passes, we were concerned that the issues raised by Lal could bias our analysis in two ways. If average height varied by the ease or difficulty of recruitment, taller recruits being obtained in times of famine when recruiters could be more selective of who to accept, this bias would prevent us from adducing any possible secular change in height from our data. And if a minimum height restriction was in operation, possibly being a major reason for the rejection of some recruits as unfit, this would prevent generalisation from the height of indentured workers to that of the wider population.

Our response to the first of these concerns was to formally incorporate demand and supply variables in our multiple regression analysis: an increase in the demand for labour from the colonies being associated, other things remaining the same, with a decrease in average height as recruiters had to seek out additional recruits by tapping a worse-off stratum of Indian society. An increase in the supply of recruits brought about by famine conditions would have been associated, other things remaining the same, with an increase in average height as recruiters would have been able to procure recruits from a better-off stratum of Indian society. 
The resulting regression analysis showed strong support for this inclusion of supply and demand factors, and in this way we could formally evaluate if there had been a secular change in height (Brennan, McDonald and Shlomowitz 1997).

We had a number of responses to the concern that a minimum height restriction, common in recruiting for the army and police, was operative. One response was to inspect the left-hand tails of the height distribution for a possible shortfall. ${ }^{1}$ Such shortfalls were not in evidence. A second response was to search for extant recruiting instructions in various archives. In the Natal Archives we discovered a number of such instructions, two of which are reproduced in the appendices to this chapter. These instructions placed importance on chest circumference, rather than on height or weight, as the main indicator of the required physical standard to perform the heavy physical labour required on overseas sugar cane plantations. For South Indian indentured workers going to Fiji, information on chest circumference was recorded on their Emigrant Passes (Brennan, McDonald and Shlomowitz 1994). And emigrants from both Calcutta and Madras had their chest measurements taken after arrival in Fiji-these measurements were summarised in unpublished minute papers in the Colonial Secretary's Office of Fiji and in the published Annual Reports on Indian Immigration, Fiji. We concluded that recruiting authorities used the information on chest measurement to indicate the physical standard of the recruit while the information on height was included for the purpose of identification.

Lal first traces broad trends in recruiting for overseas in Chapter 2, 'Places of Origin'. He shows how the initial enthusiasm for tribal labourers from Chota Nagpur shifted to the northern plains of Bihar and the United Provinces while tribal labour continued to provide the main source of labour to the Assam tea gardens (1983: 47). In our research, we have offered an epidemiological explanation for this pattern: tribals were more resistant to malaria in the tea gardens than other recruits but they were more susceptible than other groups to cholera en route to Calcutta, at the Calcutta depot, and on voyages overseas (Shlomowitz and Brennan 1990: $88,89,99)$.

1 'Tail' refers to the distribution of heights among the indentured workers, expressed as a linear graph. Usually this is seen as a bell-shaped figure. The left-hand 'tail' is the left side of this bell shape. A long left-hand 'tail' suggests that those selecting indentured workers in India had no regard for the shortness of the prospective worker, whereas a short 'tail' indicates a minimum acceptable height. 
The main focus of this chapter, however, is Lal's use of the Emigrant Passes to document the districts of origin of Fiji's indentured workers. In our research on the height of Indian workers, we followed Lal in the quantification of the districts of origin of migrants to other destinations as well as Fiji and departing from Calcutta and extended the study to those departing from Madras. During the last half of the nineteenth century, the less populous western districts of United Provinces benefited from government expenditure and the development of irrigation and railways, therefore providing opportunities for the expansion of agriculture, and the employment of share croppers and agricultural labourers. It is not surprising, then, that the recruits leaving from Calcutta came mainly from the plains districts of Bihar and, especially, eastern United Provinces where-as in Basti-population growth and the landlord-dominated agrarian structures brought economic pressure on poor agriculturists even during good seasons, while in times of flood or drought the displacement of the poorer population from districts like Gonda made them receptive to the prospects of emigration (Brennan, McDonald and Shlomowitz 1998).

In a study we made of Muslim migration to Fiji from Madras-alongside climatic factors such as the recurring droughts in North Arcotsocioreligious factors were important in creating an atmosphere where people recognised the advantages of migration. The most numerous Muslim migrants were the Mapillas of Malabar district, a group oppressed by their Hindu landlords through rack renting and unwarranted evictionssome small Mapilla bands struck back with religiously accented violence, deliberately fighting to their deaths as martyrs. Although the British recognised the causes of the unrest, their response was ineffective: for the Mapillas, indentured labour in Fiji was a release from an environment at once economically, socially and politically hostile (Brennan, McDonald and Shlomowitz 1992: 403-405).

In Chapter 3, 'Social and Economic Origins', Lal uses the Emigrant Passes to quantify the number of migrants who identified themselves as coming from specific Hindu castes, or as Muslims, or as Tribals. By comparing the resulting statistics with the numerical strength of specific Hindu castes and of the Muslim community in United Provinces society between 1891 and 1911, he concluded that, other than the Brahmins, the indentured workers formed a fair cross-section of the rural 
population. Brahmin recruits were underrepresented: whereas Brahmins made up 3.7 per cent of workers, they comprised between 8.0 per cent and 8.4 per cent of the United Province population (Lal 1983: 70).

The under representation of Brahmins can be explained by both supply and demand forces. On the side of supply, Brahmins would, in general, be less likely than other groups to be so destitute as to need to emigrate as indentured labourers. And on the side of demand, recruiters may have been hesitant to accept those Brahmins who had little exposure to hard agricultural labour. That the two sets of instructions included in our appendices specifically exclude the recruiting of Brahmins for Natal may reflect this viewpoint. Similarly, in the 1870 s, the British Guiana Emigration Agent stated: 'Brahmins are objected to in Demarara, and in future will be carefully excluded' (Bengal Emigration Proceedings 1874-75: 165).

That different colonies adopted at times different policies can be shown in the attitude of Natal's recruiting regime towards Muslim recruits, particularly in the period from 1886 to 1902 . Whereas the Muslim proportions of the overall populations of United Province and the Madras Presidency in the Census of India of 1901 were 13.5 per cent and 6.4 per cent, the proportions of Muslims departing from Calcutta and Madras to Natal between 1886 and 1902 were only 1.8 per cent and 1.4 per cent (Bhana 1991: Tables 15-17, and pp. 72-74, 79-81 for social groupings). As there was no comparable underrepresentation of Muslims going to other colonial destinations, the underrepresentation of Muslims going to Natal was brought about by a directive for Natal, as indicated in the instructions in the appendix: 'Mahomedans'/'Muhammadans' were not wanted.

The exclusion of Brahmins and Muslims in these instructions brought forth this comment from the Emigration Agent for Natal in Calcutta to the Protector of Immigrants for Natal on 6 February 1899:

I think it is a pity you should decline to receive Mahomedans, as they are far the strongest and efficient laborers, although perhaps more inclined to be turbulent than Hindus of the labouring castes. There is too a caste of Brahmins who are cultivators and not clerics, who are admirable workers in the field, usually farming their own small holdings. I do not think they should be refused, however I will guided by the form which I obtained from Madras (Indian Immigration Trust Board Papers, 1889, II/1/48, Reference No I 389/1889). 
In our research, we too used the Emigrant Passes (and Shipping Lists) to quantify the social origins of the emigrants who departed from Calcutta and Madras. But where Lal employed classifications of caste that mix ritual and socioeconomic terminology, we preferred to follow the Census of India, 1901, which classified Hindus in terms of the ritual pollution involved in transactions of food and water between members of different castes (Brennan, McDonald and Shlomowitz 1998: 55-70). The classifications were based on information provided by local informants—usually high caste- to the Census ethnographers. We constructed four general caste categories to use in our statistical analyses: high caste, superior sudra, inferior sudra and scheduled caste. ${ }^{2}$ We believed the advantage of this was that it did not pre-judge the socioeconomic position of the castes in our attempts to trace changes in wellbeing over time. In terms of migration to all the destinations, we replicated the underrepresentation of Brahmins in the emigrant population departing from Calcutta. Similarly, we found very few emigrants identifying themselves as Brahmin, Kshatriya or Vaishya departing from Madras. Even though these castes comprised 5.7 per cent of the Hindu population of the Madras Presidency in the Census of 1901, they formed only 0.15 per cent of the emigrant group (Brennan, McDonald and Shlomowitz 1994: 238).

Ralph first met Brij Lal in the late 1970s when Lal was a PhD student at ANU. Lal developed his doctoral thesis into the monograph under discussion. Ralph has followed Lal's outstanding career ever since with great interest and pleasure. When Lal convened a conference on Indian overseas migration and settlement he invited Lance to present a paper on behalf of the group, and later-after Lal became deeply involved in the writing of the Fijian constitution-Lance agreed to edit the papers given at the conference. This became a Special Issue of South Asia, entitled Across the Kala Pani (Brennan and Lal 1998). Ralph and Lance consider being Brij Lal's friend and colleague a great privilege.

2 That there was a measure of reality in the categories we employed is indicated by the demands in the 1990s for reserved educational and employment advantages similar to those enjoyed by the scheduled castes by a group calling itself the 'other backward castes'. This group comprised those castes that we denoted-somewhat inelegantly_as 'inferior sudra' (see Brennan, McDonald and Shlomowitz 2006: 117-62). 


\section{Appendix 1: Instructions to Local Agents and Recruiters working for the Government of Natal}

Length of service required of Emigrant

Age of Emigrant

Hands

Caste of Emigrant

Minors
1. The Emigrant should be fit for 5 years' field labour.

2. The men should not be more than 40 or less than 18 years of age. The married women should not be more than 35 unless they form part of a family the members of which are able and willing to support them in Natal. Single women should not be more than 30 years of age and those with one or more children will be rejected unless they form part of a batch.

3. The Emigrants' hands should show that they are agricultural labourers.

4. Non labourers such as Ex Sepoys, Office or Salt Peons, Ex Constables, Fakeers, Brahmins, Bangle makers, Artisans and Beggars must not be recruited.

5. Malayalees, Muhammadans, Emigrants returned from Natal as invalids or undesirables, Indians from Lobito Bay, Educated Indians, Indians with weak intellect or known to be suffering from fits are not wanted.

6. Minors who have quarrelled with their friends are frequently sent to Madras and are then claimed by their friends or they change their minds in a few days and express unwillingness to go to Natal. Minors, i.e., under 18 must not be recruited and in the case of youths from 18 to 20 , the Recruiter must take every possible care to satisfy himself that the Emigrant is not likely to change his mind in a day or two. 
Willingness
7. The recruiters must take care that all emigrants are really willing subjects and are not being induced by small pecuniary gifts to emigrate as these men invariably cause dissatisfaction among the other coolies in Depot.

Source: G.A. Grierson, Report on Colonial Emigration from the Bengal Presidency, Calcutta, Government of Bengal, 1883, Appendix IV.

\section{Appendix 2: Instructions for Surgeons}

When examining and selecting Emigrants in the Mofussil before proceeding to this Agency

1. The Emigrant should be, first, free from contagious disease; second, in a fit state to undergo a sea voyage of two months; third, equal to ten years' field labour.

2. The men should not be more than 35 years old, and the women not more then 30, unless they form part of a family.

3. The chest should be round and well developed; flat chested men should be rejected.

4. The hands should have horns on the palmer base of the fingers showing that the emigrant is accustomed to hard work. Fakeers, Brahmins, Kyeths, Baniahs, Mahomedans, Shop keepers, Barbers, Toddy drawers, Bangle makers, Beggars and Weavers \&c, should be rejected.

5. Cases of hernia, hydrocele and enlarged testicle should be discovered and rejected as these diseases usually develop in the colonies.

6. Bad cases of opthalmia or of diseased eyelids should be rejected. Slight opthalmia may be detained for treatment until cured. If the emigrant has lost an eye from this disease, or from any other cause on no account should he be accepted.

7. Emigrants with slight anaemia, or malarious fever, may be passed if it be considered that a few weeks' good feeding and careful treatment may put them right. Cases of enlarged spleen and chronic anaemia ought to be rejected.

8. Short Stature or slimness is not an objection if the emigrant be wiry and tough, and well able to handle agricultural implements. 
The weight of males should be nearly proportional to height, that is, 8 stone $3 \mathrm{lbs}$ for $5 \mathrm{ft}$, and $5 \mathrm{lbs}$ additional for each inch over $5 \mathrm{ft}$.

9. Emigrants suffering from slight bowel complaints should be detained till cured. The abdomen should not be flat or puckered from chronic looseness, nor inflated from habitual indigestion. All cases of chronic bowel diseases should be carefully sought for and rejected. Opium eaters, sand smokers and ganga smokers must be rejected.

10. Of contagious diseases, measles and small pox have hitherto proved most troublesome, and every suspicious case should be carefully excluded.

11. The slightest signs of leprosy; varicose veins in any part of the body; Ulcers on legs or feet, and syphilis in any form, are regarded as sufficient to justify rejection. Cases of enlarge goitre are undesirable and liable to rejection.

12. Sickly children give much trouble. Not infrequently a large family has been kept back month after month at successive embarkations on account of a weakly child. All such children should be rejected.

13. Arrangements have been made for vaccinating the emigrants here.

14. Minors, whether male or female, under 16 years of age, are not allowed to emigrate unless accompanied by a responsible relative, and should not therefore be recruited.

Robert W.S. Mitchell

Government Agent for Natal Garden Reach, Calcutta, 1889

Source: Indian Immigration Papers, II/1/48, Reference No. 389/1889, Natal Archives, Petermaritzburg.

\section{References}

Bengal Emigration Proceedings, 1874-75, India Office Records, London, $\mathrm{P} / 171$.

Bhana, Surendra. 1991. Indentured Indian Emigrants to Natal, 1860-1902: A Study Based on Ships Lists. New Delhi: Promilla.

Brennan, Lance and Brij V. Lal (eds). 1998. Across the Kala Pani: Indian Overseas Migration and Settlement. Special issue of South Asia, 21(sup. 001): 1-237. 
Brennan, Lance, John McDonald and Ralph Shlomowitz. 1992. 'The origins of South Indian Muslim indentured migration to Fiji'. Journal of the Institute of Muslim Minority Affairs, 18(2): 402-409. DOI: $10.1080 / 02666959208716261$.

_ 1994. 'Trends in the economic well being of South Indians under British rule: The anthropometric evidence'. Explorations in Economic History, 31(2): 225-60. DOI: 10.1006/exeh.1994.1010.

-1997. 'Toward an anthropometric history of Indians under British rule'. Research in Economic History, 17: 185-246 (reprinted in Brennan, McDonald and Shlomowitz 2013: 1-81).

-1998. 'The geographic and social origins of Indian indentured labourers in Mauritius, Natal, Fiji, Guyana and Jamaica'. In South Asia, 21(sup. 001): 41-55. DOI: 10.1080/00856409808723350.

- 2006. 'Caste, inequality and the nation state: The impact of reservation policies in India, c1950-2000'. South Asia, 29(1): 117-62. DOI: 10.1080/00856400600550831.

Brennan, Lance, John McDonald and Ralph Shlomowitz with Eva Aker. 2013. Well Being in India: Studies in Anthropometric History. New Delhi: Readworthy Publications.

Census of India 1901 (full text). Online: www.archive.org/stream/cu3192 4071145571/cu31924071145571_djvu.txt (accessed 7 March 2017).

Grierson, G.A. 1883. Report on Colonial Emigration from the Bengal Presidency. Calcutta: Government of Bengal.

Indian Immigration Trust Board Papers, 1889, Natal Archives, Pietermaritzburg.

Lal, Brij V. 1983. Girmityas: The Origins of the Fiji Indians. Canberra: The Journal of Pacific History.

Shlomowitz, Ralph and Lance Brennan. 1990. 'Mortality and migrant labour in Assam, 1865-1921'. Indian Economic and Social History Review, 27(1): 85-110.

Shlomowitz, Ralph with Lance Brennan and John McDonald. 1996. Mortality and Migration in the Modern World. Varorium Collected Studies Series. Aldershot: Ashgate Publishing. 
This text is taken from Bearing Witness: Essays in honour of Brij V. Lal, edited by Doug Munro and Jack Corbett, published 2017 by ANU Press, The Australian National University, Canberra, Australia. 